УДК 902.03 (477.54).551.79

DOI: https://doi.org/10.33782/eminak2020.1(29).378

\title{
О РЕЗУЛЬТАТАХ ПИЛОТНЫХ ГЕО-АРХЕОЛОГИЧЕСКИХ РЕКОГНОСЦИРОВОЧНЫХ РАБОТ В ХАРЬКОВСКОЙ ОБЛАСТИ*
}

\author{
Вадим Степанчук ${ }^{1}$ Юрий Веклич2, Сергей Палиенко ${ }^{3}$, Александр Нездолий4 \\ ${ }^{1}$ Институт археологии Национальной академии наук Украины (г. Киев, Украина) \\ e-mail: vadimstepanchuk@iananu.org.ua; ORCID: https://orcid.org/0000-0002-5476-2284 \\ 2 Украинский государственный геологоразведочный институт (г. Киев, Украина) \\ e-mail: veklych_um@ukr.net; ORCID: https://orcid.org/0000-0002-7448-9342 \\ ${ }^{3}$ Киевский национальный университет имени Тараса Шевченко (г. Киев, Украина) \\ e-mail: svpaliy777@gmail.com; ORCID: https://orcid.org/0000-0002-6258-7682
}

${ }^{4}$ Институт археологии Национальной академии наук Украины (г. Киев, Украина) e-mail: oleksandr.nezdolii@gmail.com; ORCID: https://orcid.org/0000-0001-7465-9164

Стаття присвячена викладенню результатів рекогносцирувальних робіт на відрізку правобережжя середньої течії Сіверського Дінця. Застосовувався гео-археологічний підхід, в якому геологічна компонента була провідною, археологічна - підлеглою.

Отримано пілотні дані, що дозволяють істотно коригувати напрямок можливих майбутніх досліджень ранніх етапів заселення території сучасної Харківщини. Визначено коло потенційних джерел природних барвників, уточнено склад джерел кам'яної сировини, виявлені нові палеолітичні місцезнаходження.

Територія характеризується численними оголеннями, що включають ранньоплейстоценові субаеральні відкладення.

Джерела природних барвників (відтінки червоного, синього, білого) пов'язані з відкладеннями різного геологічного віку: від тріасу-юри до першої половини квартера. Дані відкладення досить широко поширені та потенційно були доступні протягом плейстоцену.

Широко поширені у регіоні кремені, що повсюдно пов'язані з відкладеннями крейдового й юрського часу, являють собою багату сировинну базу для мисливців-збирачів різних періодів кам'яного віку. Інші різновиди сировини - крем'янисті вапняки, пісковики, кварцити, складають додаткову ресурсну базу та використовувалися стародавнім населенням.

Виявлено кілька пунктів з кам'яними виробами. Виявлені археологічні знахідки явно різночасові. Техніко-морфологічні особливості дозволяють розрізняти серед них середньопалеолітичний $і$, що особливо примітно, нижньопалеолітичний матеріали. Досліджений відрізок правобережжя Сіверського Дінця має значний потенціал для подальших досліджень палеоліту.

Ключові слова: гео-археологія, ранньочетвертичний час, природні барвники, кам'яна сировина, палеолітичні стоянки

Введение. Осенью 2019 г., в рамках выполнения проекта по исследованию символически обусловленной деятельности неандертальцев и древних форм людей,

\footnotetext{
${ }^{*}$ Исследование было частично поддержано проектом МОН Украины М/72-2019 «Междисциплинарные исследования древнейших свидетельств символического поведения в Восточной Европе».
} 
были проведены рекогносцировочные гео-археологические работы на небольшом отрезке правобережной долины среднего течения Северского Донца и ряде участков междуречья Днепр-Северский Донец. Приоритетной целью работ были поиски источников естественных материалов, которые могли использоваться древним населением в качестве красителей, а также оценка их потенциальной доступности в древности. Сопутствующими задачами ставилось укомплектование литотеки естественных пигментов, рекогносцировка мест потенциальных выходов каменного сырья, а также оценка современной степени доступности древних, раннечетвертичных отложений. Последняя задача также рассматривалась как приоритетная в виду ставшей в последние годы актуальной для украинского палеолитоведения тематики исследования нижнего (древнего, раннего) палеолита.

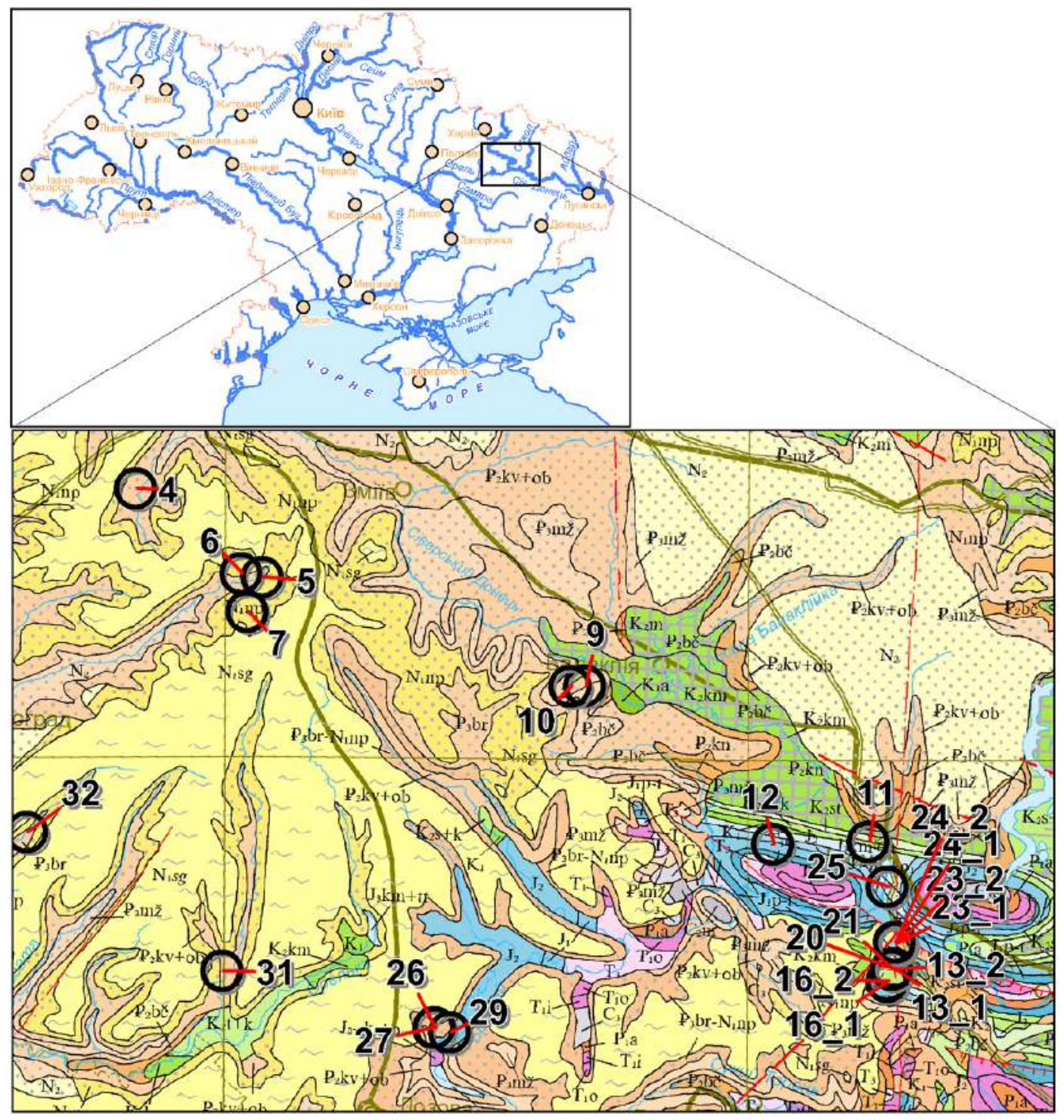

Рис. 1. Расположение пунктов исследования и их номера на фрагменте геологической карты Украины масштаба 1:1 000000 (2007). 
Интерес к региону правобережья Северского Донца дополнительно был обусловлен недавними находками Н.Ф.Торяника (г. Гадяч) в долине р. Вшива (бассейн Днепра). Здесь были выявлены каменные изделия архаического облика, сырьем для которых служил материал, вероятно происходивший из района среднего течения р. Бритай (бассейн Северского Донца).

Особо следует подчеркнуть, что задача археологического поиска не ставилась. Выявленные нами в процессе проведения рекогносцировочных полевых работ археологические находки являются сопутствующим продуктом примененной геоархеологической методики. Геологическая и геоморфологическая компонента наших работ была ведущей, археологическая - подчиненной. Вместе с тем, в данной работе главный акцент сделан на представлении сопутствующих археологических находок.

Методы. В качестве рамочного, нами использовался гео-археологический подход. В его основе лежит представление о взаимосвязи и взаимодействии древнего человека и геосферы его обитания. Тип и особенности социокультурных адаптаций в палеолитическое время во многом определялись палеоклиматическими условиями. Эти условия, в той или иной мере, отражались в специфике палеоландшафтов. В свою очередь, особенности палеоландшафтов определяли формы взаимодействия древних социумов и природной среды. Способом для получения дополнительных данных для реконструкции различных аспектов такого взаимодействия на разных временных срезах, является поиск привлекательных для обеспечения жизнедеятельности древних обществ точек в палеорельефе. Наши работы были сфокусированы на выявлении участков, в пределах которых, в раннечетвертичное время, древнему человеку потенциально были доступны источники природных красителей, выходы каменного сырья, а также располагались палеоландшафтные локусы (палеоурочища, палеопобережья и пр.), благоприятные для заселения и путей миграций.

Для выполнения полевой части работы были использованы доступные картографические материалы (топографические, геологические и почвенные карты различных масштабов (в том числе 1:1 000000 и 1:200 000), визуальные фотодокументы, опубликованные источники об ареалах и точечных пунктах наиболее вероятного нахождения выходов природных красителей и каменного сырья и древних почвенных отложений 1 , а также открытые данные о древних покровных отложениях региона (http://geoinf.kiev.ua), открытые базы снимков поверхности из космоса (Google Earth pro, v.7.3.2.5776), открытые базы топографических карт (http://dgm.gki.com.ua).

Работе в поле предшествовала проработка доступных источников, составление маршрутных листов, учитывающих посещение и непосредственное обследование наиболее перспективных участков. Далеко не все из них были действительно осмотрены; из-за нехватки времени и средств были обследованы лишь некоторые из

\footnotetext{
1 Державна геологічна карта України масштабу 1:200 000, аркуші М-37-XIII (Бєлгород), М-37-XIX (Харків) / Ю.А. Борисенко та ін. Київ: Міністерство охорони навколишнього природного середовища України, «Південекогеоцентр», 2008. 161 с.; Геологическая карта СССР масштаба 1:200 000, лист M-37-XXVI / М.Н. Клюшников и др. Москва: Государственное научно-техническое издательство литературы по геологии и охране недр, 1961. 125 с.; Проць Л.П. Державна геологічна карта України масштабу 1:200 000, аркуші M-37-XXV (Лозова). Київ: Міністерство охорони навколишнього природного середовища України, Державна геологічна служба, Донецьке державне регіональне геологічне підприємство «Донецьк-геологія», УкрДГРІ, 2007. 132 с.; Національний атлас України / Л.Г. Руденко (голов. ред.). Київ: ДНВП «Картографія», 2007. 435 с.
} 
пунктов. Ряд потенциально интересных пунктов осмотрен не был, поскольку доступ к ним был закрыт частными владельцами участков. Определяющими для выбора конкретных точек исследования были параметры геологических и геоморфологических характеристик, а также чисто технические соображения: удобства подъезда, экономии времени и топлива. Траектории пеших маршрутов каждого участника на конкретной точке были рандомными и, главным образом, определялись профессиональными интересами и подготовкой.

Фиксация местоположения: Местоположение каждого пункта исследования и большинства гео-археологических объектов (фрагментов природного красителя, местоположения их в разрезе, обломков каменного сырья в переотложенном или непотревоженном положении и пр.) фиксировалось путем фотографирования с одновременным определением GPS координат (гетерированием). Местоположения пунктов исследований также контролировалось программно-аппаратными средствами на базе смартфонов с цифровым картографическим материалом топографического, геологического и геологического содержания. Для фиксации значимых объектов использовалась также фототехника, позволяющая привязывать изображение непосредственно к выбранной системе координат.

В процессе полевых и лабораторных работ использовались: внедорожник УАЗ 31638 (2015 г.в.), Prestigio multiphone PSP 5517 DUO с программным приложением «AndroiTS GPS Test», бинокулярний микроскоп «МБС-9», фотокамера «Nikon Coolpix AW130». Для определения цвета образцов красителей использовался стандартный Munsell soil color chart.

Материалы и результаты. В общей сложности, протяженность маршрута на участке правобережной долины среднего течения Северского Донца, а также ряде участков днепро-донецкого междуречья составила более 200 км. Была осмотрена 31 точка (рис. 1), составлена значительная база фото- и аудиоматериалов. Отобрано несколько образцов потенциальных природных красителей, образцы каменного сырья, небольшие серии каменных артефактов. Все вещественные материалы в настоящий момент находятся в Институте археологии НАНУ, в отделе археологии каменного века.

Природные красители.

Поиск естественных красителей выявил, в общем-то, естественную, но не очень очевидную закономерность. В качестве источников красителей повсеместно могли выступать древние почвенные отложения, образовавшиеся в периоды теплого и влажного климата. В таких условиях почвы отказываются насыщенными оксидами железа и марганца, а также содержат большое число глинистых частиц и приобретают достаточно яркую красно-бурую окраску. При наличии экспонированных выходов, такие запасы потенциальных красящих веществ оказываются вполне доступными. В условиях развитой овражно-балочной системы, вероятность проявления и обширность простирания таких отложений возрастают, вероятность доступности их в палеолитическое время, соответственно увеличивается. Наиболее вероятными поставщиками красителей в виде погребенных почв, являются отложения крыжановского и береговского этапов, более легкодоступные, в сравнении, например, с более древними (плиоценовыми и позднемиоценовыми). Плиоценовые и позднемиоценовые субтропические почвенные отложения также имеются на территориях, на которых проводились наши рекогносцировочные работы. Как правило, они связаны с водораздельными участками и перекрыты более молодыми отложениями, 
однако их выходы отмечаются на крутых денудационных склонах. Совокупные данные указывают также на длительную, на протяжении плиоцена и плейстоцена, экспозицию этих отложений, а также перекрываемых ими карбонатных пород с кремнями. Следовательно, эти отложения были вполне доступны для древнего человека.

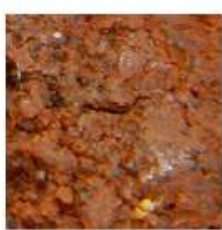

a
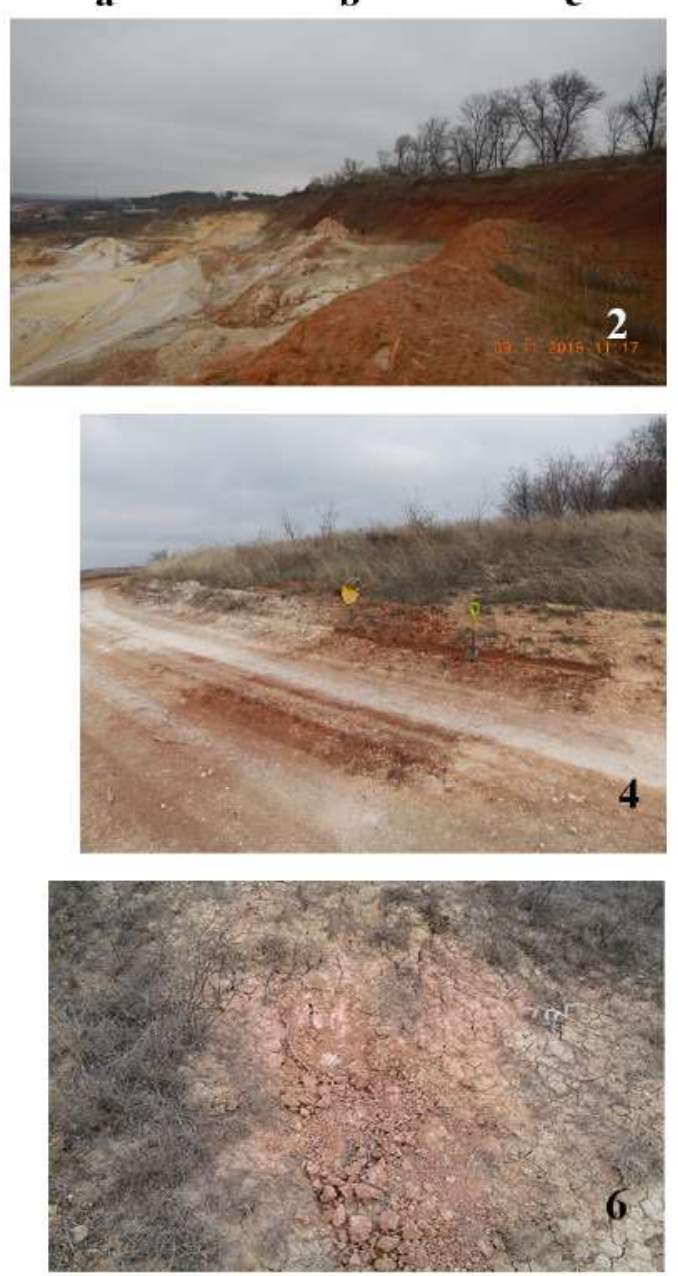

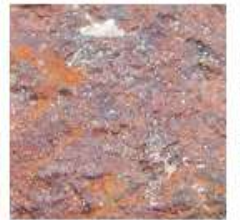

d
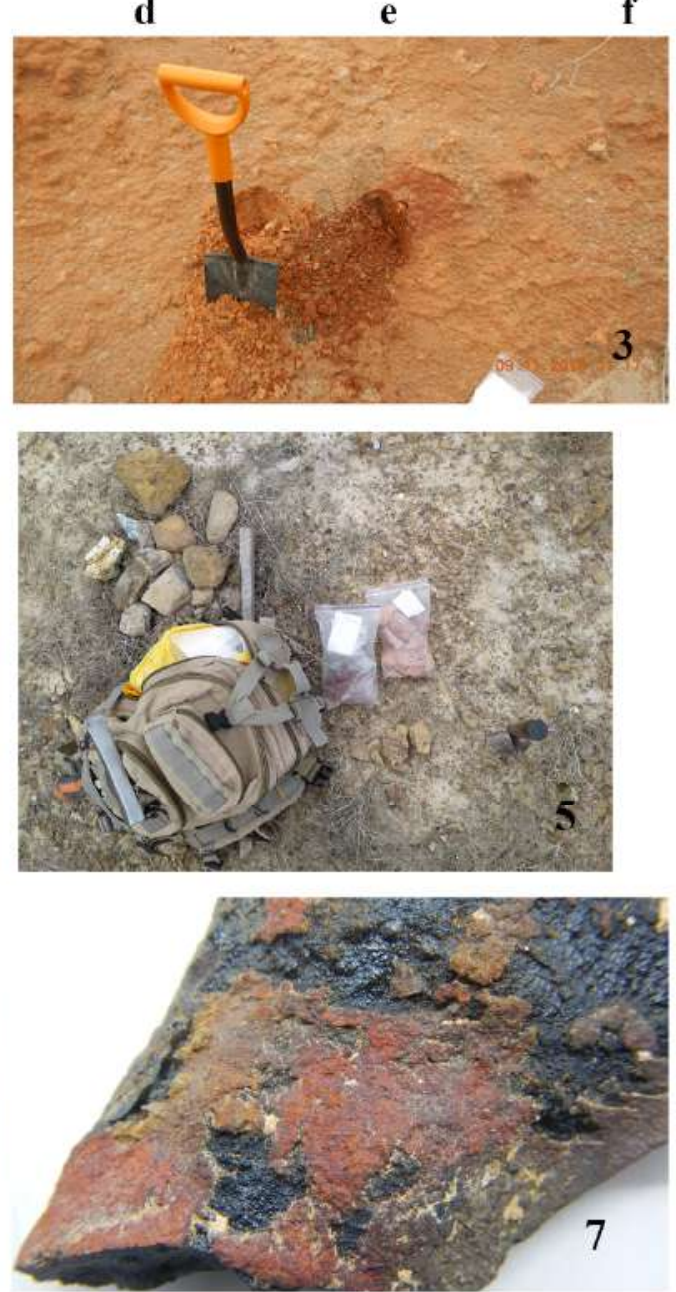

Рис. 2. Естественные красители и их контекст. 1 - образцы красителей, увеличение ×4; 2, 3 - крыжановские отложения у с. Новоселовка, 4 - поздне-миоценовая почва в карстовой западине у с. Каменка, 5, 6 - покровные отложения, перекрывающие юру у с. Каменка, 7 - гетит из плиоценовых отложений, перекрывающих юру у с. Каменка. 
В отложениях разного времени встречаются железистые и железистомарганцевые новообразования и включения, которые также вполне могли использоваться в качестве естественного красителя. Однако они, в силу высокой твердости, нуждались в предварительном измельчении.

Практика использования древними обитателями территории Украины самых разнообразных материалов для получения пигментов описывается для верхнепалеолитических памятников Украины², красители широко использовались в мустьерских памятниках.

В качестве примера местонахождений с почвами, насыщенными оксидами железа и приобретшими, в зависимости от степени насыщенности ими, разные оттенки красного цвета, можно привести отложения крыжановского этапа у сс. Новоселовка (рис. 2: 1a, 2,3) и Меловая (рис. 2: 1b), розовые и бордовые глинистые отложения триас-юрского возраста были отмечены у с. Каменка, (рис. 2: 1c, 4). Местами триасюрские отложения у с. Каменка (рис. 2: 5) содержат фрагменты образований, по твердости и структуре напоминающих гетит (рис. 2: 1d, е,7). Выходы на поверхность ярких красноцветных пород позднемиоценового возраста отмечены также на верхнем склоне долины р. Сухая Каменка неподалеку от сс. Тихоцкое и Каменка. Образцы различаются по цветности, так, согласно Munsell: a - 2,5 YR 6/8, b - 5 YR 5/6, с - 5 YR 5/8, d - 10 R 7/3, е - 4/5B.

Особо следует подчеркнуть высокий потенциал средне-, нижнеюрских и верхнетриасовых пород в роли поставщиков природных красителей. Так, в разрезах близ с. Каменка регулярно наблюдаются выходы на дневную поверхность пород древних (триас-юрских) континентальных глин и песков. Геоморфологические и геологические данные свидетельствуют о том, что они были обнажены на протяжении всего плейстоцена и могли служить прекрасным пигментно-красящим материалом для древнего человека.

Отдельный аспект представляют собой минеральные красители другой, нежели красная, цветности. Так, на территории исследованного участка повсеместно встречаются мелы - потенциальные поставщики светлых пигментов. Их цветность довольно отличается от точки к точки, так, образец из окрестностей Каменки, приведенный на рис. 3: 1f, определяется по Munsell как 5Y 6/3, бледно-зеленоватый. В районе карьера близ с. Меловая обнаружены два типа потенциального минеральнокрасочного сырья: нижнеплестоценовые темно- и красно-бурые глины (в кровле разреза) и светло-сизые мергели палеогенового возраста (киевская свита), перекрытые маломощной толщей аллювиальных песков. Последние являются потенциальнм источником светло-синего красителя. Геоморфологические данные (в частности, глубина расчлененности рельефа) свидетельствуют о высокой вероятности существования обнаженности здесь палеогенового мергеля, кремнесодержащего аллювия с овальными уплощенными кремневыми гальками, а так же плейстоценовых темно- и красно-бурых глин как минимум с раннего плейстоцена.

\footnotetext{
2 Главенчук А.В. Пігментна вохра за даними досліджень пізньопалеолітичного поселення Анетівка 2 // Кам'яна доба України. 2017. № 17-18. С. 144-145.

3 Степанчук В.М., Нездолій О.І., Вєтров Д.О. Природні барвники в матеріалах багатошарової мустьєрської стоянки Пролом II // Археологія і давня історія України. 2018. № 3 (28). С. 7-21; Степанчук В.Н. Особенности социальной структуры неандертальского общества (по материалам среднего палеолита Крыма) // Stratum plus. 2018. № 1. С. 43-57.
} 

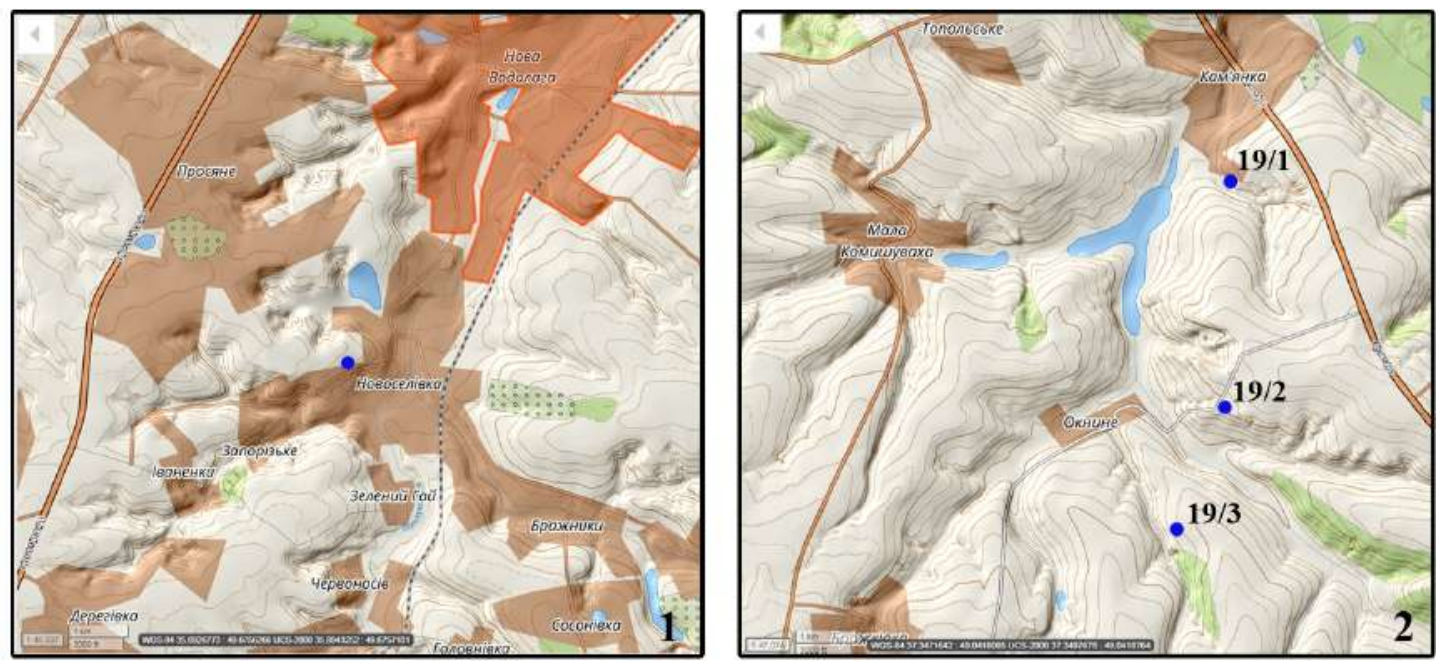

Рис. 3. Положение пунктов с археологическими находками. 1 - Новая Водолага-Новоселовка, 2 - Каменка, пункты 19/1, 19/2, 19/3. Топографическая основа: http://dgm.gki.com.ua/.nmh

\section{Пункты с археологическими находками.}

Новая Водолага - Новоселовка (Нововодолажский р-н). В верхней части среза южной бровки песчаного карьера Голубое озеро (Рис. 1: 4; 3: 1), на высоте 161-162 метра над уровнем моря, в осыпи буроцветных покровных суглинков (палеопочва широкинского возраста) обнаружено два предмета. По геологическим указаниям эти предметы обнаружены в некоренном залегании, то есть привнесены в породу извне.
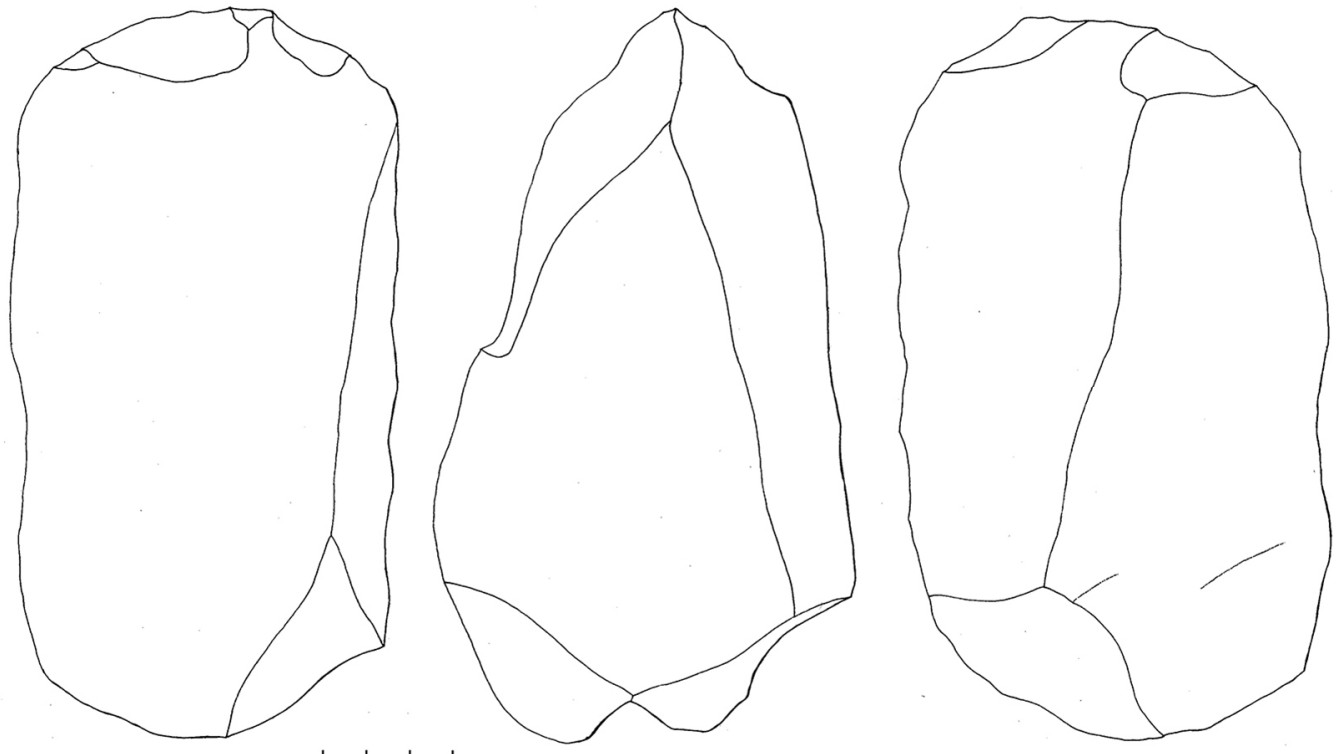

Рис. 4. Новая Водолага - Новоселовка, фрагмент песчаника с признаками обработки и/ или использования. Масштаб в см. 

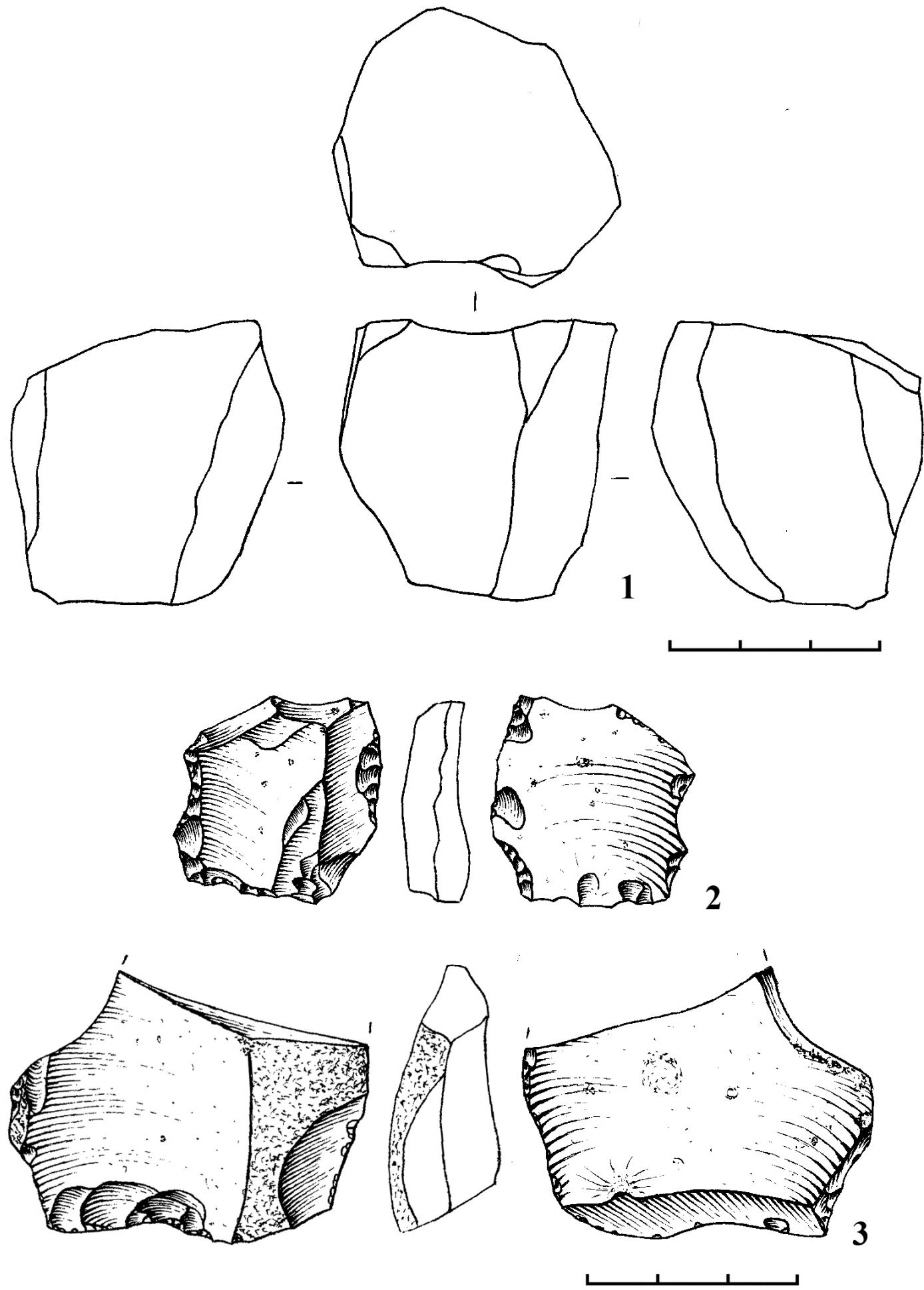

Рис. 5.1 - Новая Водолага - Новоселовка, изделие из кварцита, 2, 3 - Каменка, пункт 19/3, кремневые изделия. Масштаб в см. 
Один из них представляет собой крупный фрагмент плотного мелкозернистого песчаника, поверхности коричнево-палевые, эродированные. Представляет собой фрагмент пластовой отдельности, размеры $16 \times 9 \times 7$ см. Сохранность практически однотипная, но есть участки лучше сохранившиеся, возможно связанные с разрушением (расслаиванием) первоначального предмета, а также оббивкой (?). Обе торцевые поперечные кромки несут следы использования в виде негативов и забитостей. Одна из кромок клиновидная в профиле («рубящая»), вторая - уплощенная (рис. 4). На поверхности прослеживаются также повреждения, напоминающие нарезки, длина их достигает 3 см, ширина и глубина 1 и 0.2 мм, соответственно.

Неподалеку был найден также обломок среднезернистого серого кварцита, размерами 4.5×3.8×3.8 см (рис. 5: 1). Поверхности слегка оглажены (некоторые кромки более острые на ощупь), на поверхности - участки (припайки) ожелезнения. По особенностям поверхности устанавливается направление импульсов. Общее впечатление - предмет получился в результате биполярного расщепления, ориентация менялась в процессе обработки.

Происхождение кварцита остается неясным, что касается песчаника, он, скорее всего местный и происходит из близ расположенного локального источника (консолидированные прослои в толще кварцевых палеогеновых песков вскрываются карьером Голубое озеро). Геоморфологически точка сборов приурочена к участку водораздела близ левого борта крупной балки, впадающей в долину реки Ольховатка. Перепад высот между уровнем находок и уровнем современной долины достигает 40-45 м, расстояние по прямой до устья балки - менее 1 км.

Каменка, пункт 19/1 (Изюмский р-н). В краевой зоне водораздельного участка в верхней части бортов овражка, впадающего в слабо обводненную балку, устье которой выходит в долину р. Грековки (рис. 1:24-1; 3: 2, 19/1), среди значительного числа кремневых галек, конкреций и стяжений, на поверхности высотой 99-100 м (превышение над ближайшим действующим водотоком составляет 20-25 м) встретилось небольшое число предметов, демонстрирующих признаки намеренной модификации. Среди находок: сколы, в том числе с ретушью и/ или ретушью использования, обломки галек и плитчатых отдельностей кремня с признаками обработки. С морфологической точки зрения, представлены чопперы, фрагменты галек, сколы (рис. 6). Формально можно различать также два изделия с конвергентными, сведенными в острие, лезвиями. С технической точки зрения, представлены предметы, преимущественно полученные в технике биполярного расщепления на наковальне. Лишь некоторые предметы, предположительно, были оббиты (ретушированы) в технике расщепления на весу. Некоторые предметы позволяют реконструировать смену положения предмета в процессе биполярной обработки. Интерес представляют выявленные на нескольких изделиях зоны с большим числом точек соударения с твердым предметом. На одном из них, на участке примерно $5 \times 1$ см насчитывается до 20 таких точек! Судя по местам локализации, такие повреждения, технически, скорее всего, возникли в процессе попыток намеренной фрагментации или отсечения кромок. Обращает на себя внимание зеленовато-коричневатая патина на большей части предметов. Предметы с белой патиной редки, хотя и имеются. Такая патина покрывает лишь отдельные участки изделий и не очень интенсивна. Поверхности негативов и сломов довольно интенсивно оглажены. Многие кромки характеризуются мелкой забитостью. Преобладают поделки из высококачественного тонкоструктурного кремня серых оттенков, иногда с пятнистой или слойчатой зо- 
нальностью. Распространены также цветные кремни, преимущественно коричневые. Состав, метрические и морфологические характеристики предметов с признаками обработки соответствуют таковым параметрам естественных отдельностей кремневого сырья. Поверхности изломов естественных фрагментов часто также покрыты такой же зеленовато-коричневатой патиной. Предметы с белой, иногда изжелта белой патиной также встречаются. Среди изделий имеется скол из серого среднезернистого кварцита; в просмотренной нами случайной выборке естественных обломков такое сырье зафиксировано не было. Отмечено наличие кварцевых галек, как правило, небольших размеров, с максимальными размерами до 4-5 см. Подобная галька, с признаками намеренной фрагментации, представлена и среди изделий. В целом, характеристики физической сохранности материала указывают на длительное пребывание многих предметов в насыщенной водной среде (интенсивная оглаженность, зеленовато-коричневатые оттенки патины). 0 субаэральном залегании сигнализируют предметы с частичной белой патиной. В этой связи интересно, что кварцитовый отщеп также патинирован на локализованном участке, что позволяет реконструировать его длительное залегание на ребре, в положении лишь частичной заглубленности в седименты.
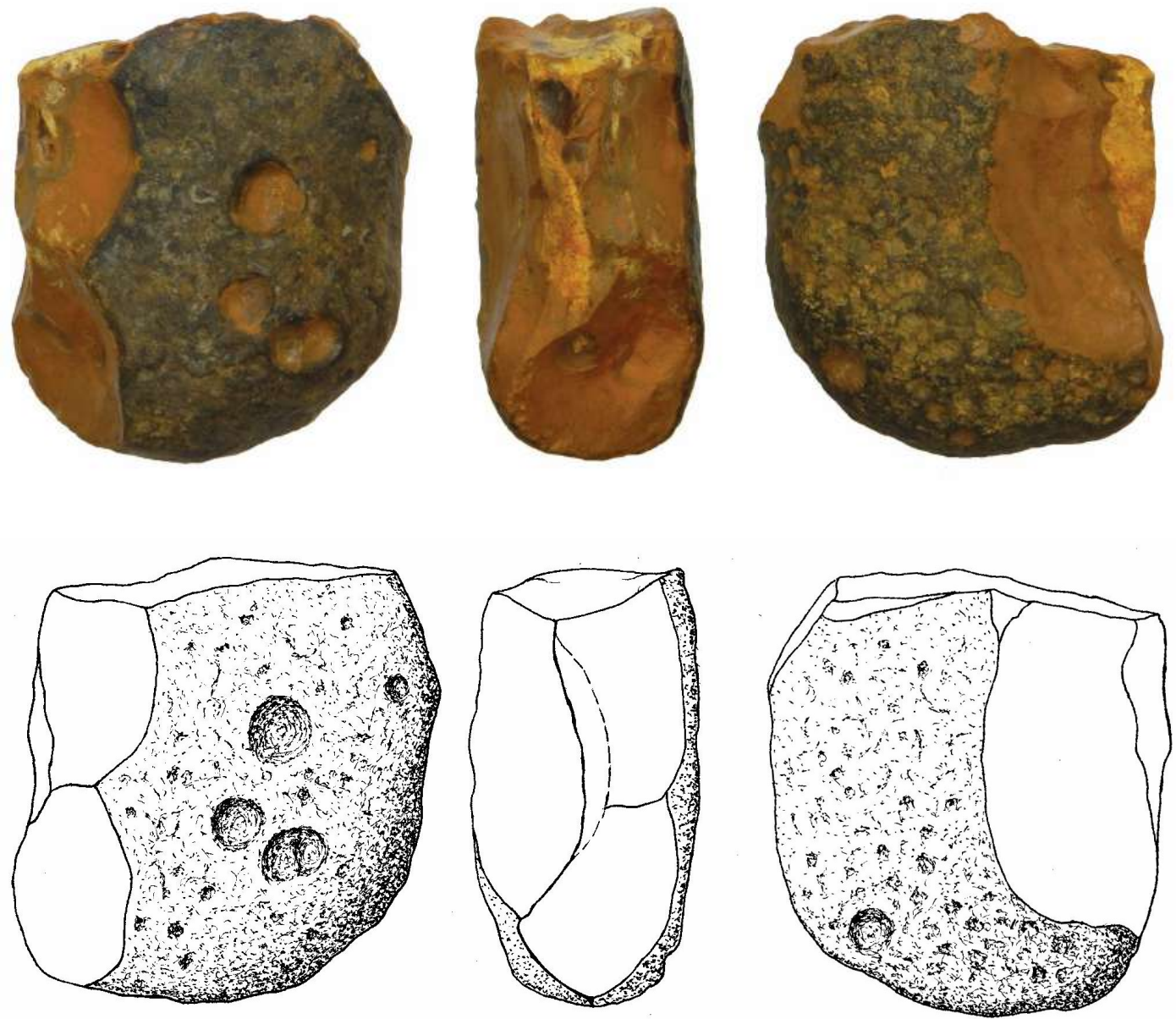

Рис. 6. Каменка, пункт 19/1, изделие на гальке, фото и прорисовка. Масштаб в см. 
Каменка, пункт 19/2 (Изюмский р-н). На водораздельном участке с высотами 145-146 м над уровнем моря (рис. 1:13; 3: 2, 19/2), на пахоте, среди большого числа природных кремней, с примесью небольших фрагментов известняка (мергеля ?) и мелких галечек кварца, найдено несколько артефактов. Представлены отщепы, массивный реберчатый скол, нуклевидные обломки, а также двусторонне оббитая овальная в плане преформа. Один из предметов побывал в огне. Сырье поделок: серый с более светло окрашенными зонами, высококачественный тонкозернистый кремень. Находки в разной степени покрыты бело-голубой патиной, как правило, не сплошной. Примечательно, что одна из поверхностей предметов либо менее патинирована, либо (и чаще всего) практически лишена патины. Разницу физического состояния поверхностей предметов следует объяснять длительным нахождением артефактов в стабильной пространственной позиции. С другой стороны, эти же признаки говорят о том, что артефакты, возможно с самого момента изготовления, практически не перекрывались седиментами. Затруднительно с точностью определить археологический возраст найденных артефактов, но, учитывая небрежность обработки, тип сохранности, тенико-морфологические характеристики, можно предполагать их принадлежность завершающим этапам каменного века. Керамика на участке не встречена.

На длительную экспонированность кремневых объектов данного участка указывает и состояние естественных кремней, представляющих собой фрагментированные конкреции (до $10 \times 6 \times 5$ см), реже гальки (до $10 \times 7 \times 4.5$ см). Кремни, как правило, патинированы, патина довольно интенсивная, часто молочно-белая. В то же время, имеется много предметов с участками разнотипной патины. Кремни, как правило, фрагментированы; часты морозобойные повреждения. Найдено несколько «нуклевидных» предметов с участками, которые скорее напоминают негативы намеренных снятий, нежели чем естественные сломы. Они, возможно, являются отходами опробывания сырья. Кремень качественный, тонкозернистый, серый, реже светлосерый, с крупными более светлыми зонами и тонкой коркой. Параметры сырья артефактов полностью соответствуют характеристикам природных кремней. Следует отметить, что в глубоких промоинах - молодых овражках по восточному склону рядом, в 300-400 м к западу, расположенной сухой балки, на осыпях и непосредственно во включающем рыхлом материале, на уровне порядка 120-123 м, представлены более разнообразные в цветовом отношении высококачественные кремни в виде крупных конкреций и стяжений. Общая сохранность сырья здесь ощутимо выше, чем на поверхности водораздельного участка.

Каменка, пункт 19/3 (Изюмский р-н). Здесь на поверхности межбалочного водораздела с высотами порядка 136-138 м над уровнем моря был зафиксирован участок с находками обработанного кремня (рис. 1: 16-1; 3: 2, 19/3). Площадь сборов примерно 100×100 м. Кремень, серый, тонкозернистый, с тонкой коркой. Поделки, очень часто фрагментированные, покрыты глубокой (до 1-1.2 мм) молочнофарфоровой патиной, поверхности оглажены, иногда наблюдаются морозобойные повреждения поверхностей. Часть находок, возможно, имеет ретушированные кромки и кромки с ретушью утилизации. Представлены только отщепы и их фрагменты (рис. 5: 2, 3). Отмечены гладкие и точечные площадки, огранка преимущественно подпараллельная, есть единичные покрытые коркой и центростремительно ограненные сколы. Коллекция небольшая, диагностичные предметы отсутствуют, однако по сумме имеющихся признаков можно допускать мустьерский возраст колле- 
кции. Здесь же поднято несколько слабопатинированных или непатинированных сколов, в том числе из коричневого кремня, также с оглаженными поверхностями. Предметы явно относятся к более позднему времени. Керамика на участке не встречена.

Серые тонкозернистые кремни в виде небольших, часто пальцевидных конкреций, покрытых тонкой коркой, встречены в природных обнажениях юрского периода на склонах балки к западу от места сборов, на небольшом, до 200 м, удалении от него. Эти выходы, возможно, служили источником сырья для поделок патинированного комплекса находок. Здесь же, на этих выходах встречены небольшие черные плоские кремневые гальки и суб-сферические кварцевые галечки. Следует заметить, что подобные предметы встречались и на участке с патинированными сколами, однако не имели несомненных признаков обработки.

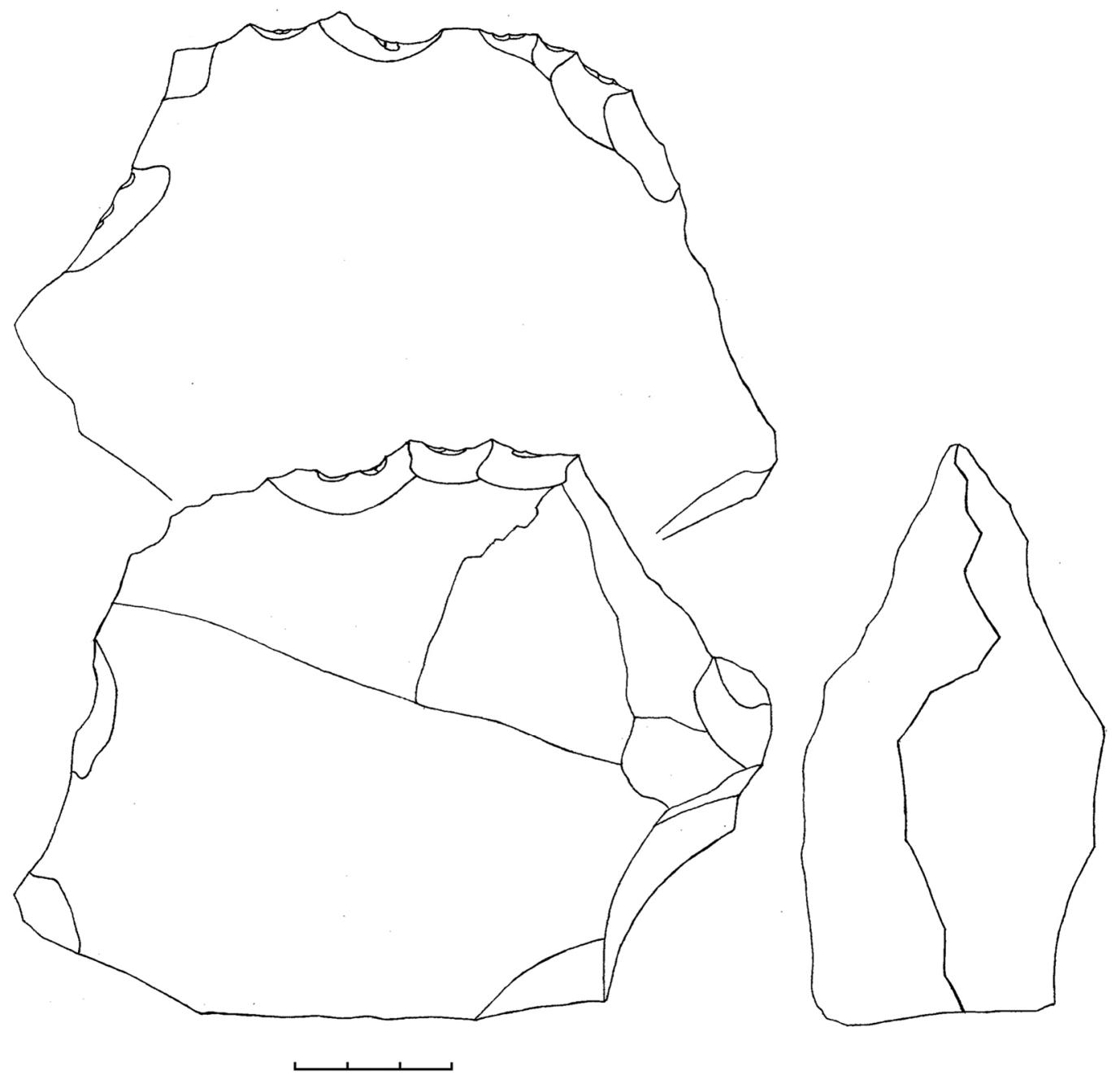

Рис. 7. Смирновка. Изделие из местного кремнистого известняка с признаками обработки и использования. Масштаб в см. 
Смирновка (Лозовский р-н). На водораздельном участке с высотами 142-143 м над уровнем моря (рис. 1:27), на поверхности современных почв, сформировавшихся на раннечетвертичных (широкино) почвах, у южной кромки Смирновского карьера, было локализовано пятно предположительных поделок из местного кремнистого известняка. Пласты этого материала в естественном залегании в настоящий момент наблюдаются на нижних уровнях карьера (высоты 112-118 м), большей частью на сегодня заброшенного. Высказанное ранее Н.Ф. Торяником предположение об аналогичности сырья поделок, выявленных на местонахождениях Бабаки и Андреевка, удаленных к северо-востоку на расстояние в 60 км по прямой, и смирновских кремнистых известняков можно считать полностью подтвержденным. В палеолитическое время этот материал мог быть доступен в виде ограниченно экспонированных выходов в устье смирновской балки, открывающейся к юго-востоку в долину р. Бритай, а также на соседних участках долины реки. Следует отметить, что наличие этого камня и сегодня отмечается в небольших карьерах ниже по течению р. Бритай, на высотах порядка 118 м н.у.м. Предметы, выявленные на пахоте, демонстрируют признаки намеренного биполярного расщепления и, предположительно, использования (рис. 7). Остается открытым вопрос о возрасте этих находок. Никаких внятных указаний на этот счет не выявлено, однако физическая сохранность собранных у Смирновского карьера предметов однозначно более лучшая, нежели предметов, обнаруженных в долине р. Вшивой. Напомним, что в типологическом отношении упомянутые коллекции содержат рубящие формы, единичные изделия с ретушью и ретушью утилизации, сколы и осколки биполярного расщепления. С технологической точки зрения, коллекции Бабаков и Андреевки характеризуются преобладанием биполярного расщепления (дробления на наковальне), продукты свободного расщепления на весу, включая бифасиальные предметы, встречаются, но редки ${ }^{4}$.

Обсуждение. Прежде всего, следует отметить очень широкое распространение в регионе изотропных пород, которые представляли собой богатую сырьевую базу для охотников-собирателей различных периодов каменного века. Кремни повсеместно связаны с отложениями мелового и юрского времени по правобережью Северского Донца. Наблюдается некоторая разница в метрических и морфологических параметрах кремневых конкреций и стяжений разного возраста образования, в частности для юрских отложений более характерно наличие плоских кремневых галек. Однако более существенной представляется разница между кремнями из проявлений, перекрытых отложениями (первичные выходы), и длительно экспонированных проявлений (вторичные, частично переотложенные, выходы). Ассортимент потенциального сырья в последнем случае хуже и в количественном, и в качественном отношении.

В отношении закономерностей проявления естественных красителей в предварительном плане установлено, что потенциальные источники связаны с отложениями разного геологического возраста: от триаса-юры до первой половины квартера. С учетом происхождения, степени распространенности соответствующих отложе-

\footnotetext{
${ }_{4}^{4}$ Степанчук В.Н. Ключевые нижнепалеолитические памятники запада восточно-европейского ареала Украины // Палеолитическая стоянка Азых в Азербайджане и миграционные процессы. Баку, 2018. С. 149-161; Звіт про НДР 01180001457 «Найдавніші палеолітичні стоянки України в контексті початкової колонізації Європи» / В.М. Степанчук та ін. Київ: УкрIHTEI, 2018. 77 с.
} 
ний, а также меры их экспонированности (и, следовательно, доступности) для изученной территории могут различаться несколько условных групп минеральных красителей. Это красно-бурые и красновато-бурые раннечетвертичные глины (широкое распространение, сравнительная доступность), кирпично-красные и бурокрасные позднемиоценовые глины (достаточно широкое распространение, сравнительная доступность); светло-сизые мергели палеогена (сравнительная доступность); мелы белые и серые; бордовые, охристые глинистые триас-юрские континентальные седименты (достаточно широкое распространение, сравнительная доступность).

В археологических источниках регион в первую очередь характеризуется как богатый естественными отложениями мелового возраста с многочисленными кремнями 5 . Кремни туронского и сеноманского ярусов мела высококачественны, высоко изотропны, мелкозернисты. Меловый кремень широко использовался в качестве сырья для поделок на местных стоянках различных периодов.

Учитывая новые находки местонахождений с каменными изделиями на территории Харьковщины, следует напомнить основные вехи исследования палеолита регионаб.

Первые попытки исследования памятников каменного века были предприняты здесь в конце XIX - начале XX вВ. в связи с проведением XII Археологического съездаПозднее, уже в 1920-е - 1940-е гг. работы по этой тематике проводились проф. Федоровским и, главным образом, Н.В. Сибилевым ${ }^{7}$ В округе г. Изюм, в местах поверхностных выходов сырья, им было выявлено несколько пунктов, в том числе у сс. Каменка (ур. Верхний Степок), Синичено (ур. Прыстин и еще одно - в сторону с. Сухая Каменка), Яремовка. Стоянка в ур. Прыстин исследовалась Н.В. Сибилевым в 1940 и 1941 гг., два из четырех слоев были определены как верхнепалеолитические. Недавно И.А. Снежко были предприняты попытки отыскать и обследовать данные местонахождения. В 1950 г. некоторые пункты в районе г.Изюм изучались И.Ф. Левицким, в том числе совместно с Д.Я. Телегиным ${ }^{8}$. В частности, Миньевский Яр доставил достаточно выразительные верхнепалеолитические материалы. В 1972 г. М.И. Гладких, работавшим в составе палеонтологической экспедиции Института зоологии им. И.И. Шмальгаузена АН УССР, было выявлено в зоне строительства канала Днепр-Донбасс в окрестностях с. Большая Камышеваха несколько палеолитических местонахождений, в том числе, с материалом среднепалеолитического облика9.

\footnotetext{
5 Горелик А.Ф., Дегерменджи С.М. По запутанному следу: к возникновению одной неолитической стоянки-мастерской в Подонцовье. Stratum plus. 2015. № 2. С. 233-274.

${ }^{6}$ Сніжко І.А. Пам'ятки давнього кам'яного віку середньої течії Сіверського Дінця - від XII Археологічного з'їзду до сучасних досліджень // Вісник Харківського національного університету імені В.Н. Каразіна. Серія «Історія». 2019. Вип. 54. С. 63-72; Снежко И.А. История открытия позднепалеолитических памятников Изюмщины // Святогірський альманах. Донецьк, 2009. С. 49-55; Кротова 0.0. Історія дослідження верхнього палеоліту басейну Сіверського Дінця // Вісник Харківського національного університету імені В.Н. Каразіна. Серія: Історія. 2019. Вип. 54. С. 53-62.

${ }^{7}$ Сибилев Н.В. Древности Изюмщины. Вып. ІІ. Изюм: Типография Печатное Дело, 1926. 26 с.

8 Левицький І.Ф., Телегін Д.Я. Дослідження стоянки в урочищі Минівський Яр на Сіверському Дінці // Археологічні пам'ятки УРСР. 1956. т. VI. С. 183-188.

9 Гладких М.И. Разведки палеолита в зоне канала Днепр-Донбасс // Археологические открытия 1972 года. Москва, 1973. С. 268-269.
} 
Дальнейшее изучение палеолита Харьковской области связанно с деятельностью И.А.Снежко ${ }^{10}$. В 1988-2002 гг. ею исследуется позднепалеолитическая мастерская возле с. Синичено, где найдены также еще несколько пунктов с обработанным кремнем. Еще одна позднепалеолитическая мастерская была выявлена в 2004 г. в окрестностях с. Каменка, а раскопки памятника продолжались с 2005 по 2017 г. В 2015 г. И.А. Снежко в Балаклейском районе было обнаружено несколько новых местонахождений, содержащих обработанный камень верхнепалеолитического облика.

Таким образом, на территории Харьковщины известны, к настоящему моменту, только верхнепалеолитические памятники. Находки более древние до последнего времени либо не были выявлены, либо крайне недостаточно опубликованы 11. М.И. Гладких предполагает мустьерский возраст своих находок у с. Большая Комышеваха. Более древние материалы здесь известны не были. Исключением для территории Харьковщины являются, пока еще также плохо опубликованные, находки Н.Ф. Торяника в долине р. Вшивая. Для близлежащих участков Донецкой области можно упомянуть единичные находки в аллювиальных отложениях завадовского либо, что более вероятно, ранне-лубенского возраста близ Константиновки, выявленные А. Филипповым. Практически полное отсутствие в регионе более древних памятников выглядит особенно контрастно при сравнении с ближайшими соседними регионами ${ }^{12}$. Обращает на себя внимание, что ареал разведанных и частично исследованных памятников географически тяготеет к долине Северского Донца. Наша кратковременная рекогносцировка на территориях несколько удаленных к западу, в системе правых притоков Северского Донца, позволяет утверждать, что данный ареал имеет значительный потенциал для дальнейших исследований палеолита региона, в том числе и древнего. Исследованный участок характеризуется наличием сырья (кремни в отложениях юрского и мелового периодов), многочисленными обнажениями, включающими раннеплейстоценовые субаэральные отложения. Выявленные нами археологические находки явно разновременные. Технико-морфологические особенности позволяют различать среди них среднепалеолитические и, что особенно примечательно, нижнепалеолитические материалы.

Выводы. В ходе кратковременных рекогносцировочных полевых работ, проведенных в рамках гео-археологического подхода, были получены пилотные данные, позволяющие существенно корректировать направление и места проведения возможных будущих исследований ранних этапов заселения территории современной Харьковщины. Были осуществлены оценка наличия и доступности каменного сырья и красителей на протяжении плейстоцена, произведена оценка доступности об-

${ }^{10}$ Сніжко I.A. Пам'ятки давнього кам'яного віку середньої течії Сіверського Дінця - від XII Археологічного з'їзду до сучасних досліджень // Вісник Харківського національного університету імені В.Н. Каразіна. Серія «Історія». 2019. Вип. 54. С. 67-69; Сніжко І.А. Археологічні розвідки на території Балаклійського району Харківської області // Двадцять другі Сумцовські читання. Харків, 2016. С. 278-282.

11 Гладких М.И. Разведки палеолита в зоне канала Днепр-Донбасс // Археологические открытия 1972 года. Москва, 1973. С. 268-269.

12 Колесник А.В. Средний палеолит Донбасса. Донецк: Лебедь, 2003. 294 с.; Ветров В.С., Скориков В.А. Местонахождение каменного века Вишневый Дол // Проблемы охраны и изучения памятников степной зоны восточной Европы. Луганск, 2010. С. 265-271; Степанчук В.М., Вєтров В.С., Скоріков В.А. Дослідження нижнього палеоліту рівнинної України: огляд поточних даних // Кам’яна доба України. 2017. № 17-18. С. 48-65. 
нажений древних отложений и их потенциал для целевых археологических разведок. Применялся гео-археологический подход, в котором геологическая компонента была ведущей, археологическая - подчиненной.

Геоморфологическое положение относительно террасового рельефа позднекайнозойского возраста, генетико-стратиграфическое строение позднекайнозойской лессово-почвенной формации, литолого-палеопедологические данные, геологические, петрографические и пр. данные дочетвертичных пород позволяют определить участки, в пределах которых были доступны для использования древним человеком (в плейстоцене и плиоцене) в качестве сырья для минеральных красок,создания или использования природного каменного материала.

Выполнение гео-археологических исследований с применением упомянутого комплекса методов позволило выявить многочисленные участки с древним рельефом и доступными обнажениями, которые существовали с раннего плейстоцена.

Выявлены перспективные участки красителей. Они различаются по степени распространенности, а также экспонированности (и, следовательно, доступности). Некоторые из них были обследованы.

Были обследованы также отдельные участки выходов кремневого сырья (кремень в виде конкреций, желваков, галек, пластовые кремнистые известняки, песчаники и кварциты). Меловые кремни и кремни юры широко представлены в регионе и были доступными на протяжении всего плейстоцена.

В процессе работ выявлено несколько местонахождений с кремневыми изделиями. Наиболее древние могут быть отнесены к периоду нижнего палеолита.

\section{REFERENCES}

Borysenko, Yu.A., $\quad$ Horiachev, A.V., $\quad$ Lytvynenko, Yu.O., $\quad$ Myrka, H.Yu., $\quad$ Moskalenko, I.O., Moskalenko, L.H., Rudyi, M.H., \& Yakovliev, V.V. (2008). Derzhavna heolohichna karta Ukrainy masshtabu 1:200 000 [State geological map of Ukraine on the scale of 1: 200 000] (sheets: M-37-XIII (Belgorod), M-37-XIX (Kharkiv). Kyiv: Ministry of Environmental Protection of Ukraine, «Pivdenekoheotsentr» [in Ukrainian].

Gladkikh, M.I. (1973). Razvedki paleolita v zone kanala Dnepr-Donbass [Paleolithic investigations in the Dnipro-Donbas canal zone]. In Rybakov, B.A. (Ed.). Arkheologicheskie otkrytiia 1972 goda (pp. 268269). Moscow: Nauka [in Russian].

Gorelik, A.F. \& Degermendzhi, S.M. (2015). Po zaputannomu sledu k vozniknoveniiu odnoi neoliticheskoi stoianki-masterskoi $\mathrm{v}$ Podontsove [On the confusing trail: to the emergence of a Neolithic site-workshop in Podontsovye]. Stratum plus, 2, 233-274 [in Russian].

Hlavenchuk, A.V. (2017). Pihmentna vokhra za danymy doslidzhen piznopaleolitychnoho poselennia Anetivka 2 [The pigment ochre according research on Late Paleolithic site Anetivka 2]. Kamiana doba Ukrainy, 17-18, 144-152 [in Ukrainian].

Kliushnikov, M.N., Guk, V.I., Nerodenko, V.M., Dobrianskii, E.U., Roslyi, I.M., \& Bannik, G.I. (1961). Geologicheskaia karta SSSR masshtaba 1200000 [Geological map of the USSR on the scale of 1:200 000] (sheet: M-37-XXVI). Moscow: State Scientific and Technical Publishing House of Literature on Geology and Mineral Protection [in Russian].

Kolesnik, A.V. (2003). Srednii paleolit Donbassa [The Middle Paleolithic of Donbass]. Donetsk: Lebed [in Russian].

Krotova, 0.0. (2019). Istoriia doslidzhennia verkhnoho paleolitu baseinu Siverskoho Dintsia [History of study the Upper Paleolithic of the Siverskyi Donets Basin]. Visnyk Kharkivskoho natsionalnoho universytetu imeni V.N. Karazina: Seriia «Istoriia», 54, 53-62 [in Ukrainian].

Levytskyi, I.F. \& Telehin, D.Ya. (1956). Doslidzhennia stoianky v urochyshchi Mynivskyi Yar na Siverskomu Dintsi [Investigations of the site in Minivsky Yar on Siverskyi Donets]. In Yefymenko, P.P. (Ed.). Arkheolohichni pamiatky URSR (vol. VI, pp. 183-188). Kyiv: Publishing house of the Academy of Sciences of the USSR [in Ukrainian]. 
Prots, L.P. (2007). Derzhavna heolohichna karta Ukrainy masshtabu 1:200 000 [State geological map of Ukraine on the scale of 1: 200 000] (sheets M-37-XXV (Lozova). Kyiv: Ministry of Environmental Protection of Ukraine, State Geological Survey, Donetsk State Regional Geological Enterprise «Donetsk-Geology» [in Ukrainian].

Rudenko, L.H. (Ed.). (2007). Natsionalnyi atlas Ukrainy [National Atlas of Ukraine]. Kyiv: DNVP «Kartohrafiia» [in Ukrainian].

Sibilev, N.V. (1926). Drevnosti Iziumshchiny [Antiquities of Izyum region]. Izium: Printing House «Pechatnoe Delo» [in Russian].

Snezhko, I.A. (2009). Istoriia otkrytiia pozdnepaleoliticheskikh pamiatnikov Iziumshchiny [History of the discovery of Upper Paleolithic monuments of Izyum region]. In Dobrov, P.V. (Ed.). Sviatogirskii almanakh (pp. 49-55). Donetsk: Communal Institution «State Historical and Architectural Reserve in Sviatogorsk» [in Russian].

Snizhko, I.A. (2016). Arkheolohichni rozvidky na terytorii Balakliiskoho raionu Kharkivskoi oblasti [Archaeological investigations in the territory of Balakliia district of Kharkiv region]. In Soshnikova 0.M. et al. (Eds.). Dvadtsiat druhi Sumtsovski chytannia (pp. 278-282). Kharkiv: «Maidan» [in Ukrainian].

Snizhko, I.A. (2019). Pamiatky davnoho kamianoho viku serednoi techii Siverskoho Dintsia - vid XII Arkheolohichnoho zizdu do suchasnykh doslidzhen [Monuments of the ancient Stone Age in the middle course of Seversky Donets river - from the XII Archaeological Congress to modern research]. Visnyk Kharkivskoho natsionalnoho universytetu imeni V.N. Karazina: Seriia «Istoriia», 54, 63-72 [in Ukrainian].

Stepanchuk, V.N. (2018). Osobennosti sotsialnoi struktury neandertalskogo obshchestva po materialam srednego paleolita Kryma [Features of the social structure of Neanderthal society (based on the Crimean Middle Paleolithic)]. Stratum plus, 1, 43-57 [in Russian].

Stepanchuk, V.N. (2018). Kliuchevye nizhnepaleoliticheskie pamiatniki zapada vostochno-evropeiskogo areala Ukrainy [Key Lower Paleolithic Monuments of the West of the Eastern European Range of Ukraine]. In Ragimova M.N. (Ed.). Paleoliticheskaia stoianka Azykh v Azerbaidzhane i migratsionnye protsessy (pp. 149-161). Baku: Institute of Archeology and Ethnography [in Russian].

Stepanchuk, V.M., Bakhmutov, V.H., $\quad$ Matviishyna, Zh.M., $\quad$ Dmytruk, Yu.M., Veklych, Yu.M., Karmazynenko, S.P., Tsvelykh, O.M., Vietrov, D.0., \& Nezdolii, O.I. (2018). Zvit pro NDR $0118 U 001457$ «Naidavnishi paleolitychni stoianky Ukrainy v konteksti pochatkovoi kolonizatsii Yevropy» [Research report 0118 U001457 «The most ancient Paleolithic sites of Ukraine in the context of the initial colonization of Europe»]. Kyiv: UkrINTEI [in Ukrainian].

Stepanchuk, V.M., Nezdolii, O.I., \& Vietrov, D.o. (2018). Pryrodni barvnyky v materialakh bahatosharovoi mustierskoi stoianky Prolom II [Natural pigments in materials of the multilayered Mousterian site of Prolom II]. Arkheolohiia i davnia istoriia Ukrainy, 3 (28), 7-21 [in Ukrainian].

Stepanchuk, V.M., Vietrov, V.S., \& Skorikov, V.A. (2017). Doslidzhennia nyzhnoho paleolitu rivnynnoi Ukrainy: ohliad potochnykh danykh [Studies on the Lower Palaeolithic of the Open Landscapes of Ukraine: overview of the current data]. Kamiana doba Ukrainy, 17-18, 48-65 [in Ukrainian].

Vetrov, V.S. \& Skorikov, V.A. (2010). Mestonakhozhdenie kamennogo veka Vishnevyi Dol [The location of the Stone Age Vishnevyi Dol]. In Vasilenko A.I. (Ed.). Problemy okhrany i izucheniia pamiatnikov stepnoi zony vostochnoi Evropy (pp. 265-217). Luhansk: Globus [in Russian]. 
Vadym Stepanchuk

(Institute of Archaeology National Academy of Sciences of Ukraine, Kyiv, Ukraine)

ORCID: https://orcid.org/0000-0002-5476-2284

\section{Yurii Veklych}

(Ukrainian State Geological Exploration Institute, Kyiv, Ukraine)

ORCID: https://orcid.org/0000-0002-7448-9342

\section{Sergii Paliienko}

(Taras Shevchenko National University of Kyiv, Kyiv, Ukraine)

ORCID: https://orcid.org/0000-0002-6258-7682

\section{Oleksandr Nezdolii}

(Institute of Archaeology National Academy of Sciences of Ukraine, Kyiv, Ukraine)

ORCID: https://orcid.org/0000-0001-7465-9164

\section{On the Results of Pilot Geo-Archaeological Reconnaissance in Kharkiv Region}

The paper is devoted to the presentation of the results of the reconnaissance on the Siverskyi Donets middle course right bank segment. A geo-archaeological approach is used, in which the geological component is the leading one, and the archaeological component is the subordinate one.

Pilot data that allow to substantially modify the area of possible future studies of the early stages of the modern Kharkiv region territory colonization are gained. The range of natural dyes potential sources is determined, the composition of the sources of stone raw materials is specified, and new Paleolithic sites are found.

The territory is characterized by numerous outcrops, including the Early Pleistocene subaerial sediments.

The sources of natural dyes (shades of red, blue, white) are associated with the sediments of different geological age: from the Triassic-Jurassic to the first half of the Quaternary. Enclosing sediments are quite widespread and were potentially available throughout the Pleistocene.

Flints, widespread in the region, are universally associated with the Cretaceous and Jurassic sediments and represented a rich resource base for hunter-gatherers of various periods of the Stone Age. Other varieties of raw materials - different types of siliceous limestone, sandstone, and quartzite made up an additional resource base and were used by the prehistoric population.

A few sites with lithic produced items are discovered. The found archaeological artifacts are obviously noncontemporaneous. Technical and morphological features make it possible to distinguish among them the Middle Paleolithic and, the most noteworthy, the Lower Paleolithic evidence. The studied segment of the right bank of the Siverskyi Donets has significant potential for further studies of the Paleolithic.

Keywords: geo-archaeology, Early Quaternary, natural dyes, lithic raw materials, Paleolithic sites 